\author{
Waldemar Odziemczyk \\ Dr inż. \\ Wydział Geodezji i Kartografii, Politechnika Warszawska \\ waldemar.odziemczyk@pw.edu.pl
}

\author{
Marek Woźniak \\ Dr hab. inż. prof. PW \\ Wydział Geodezji i Kartografii, Politechnika Warszawska \\ marek.wozniak@pw.edu.pl
}

DOI: 10.35117/A_ENG_18_08_05

\title{
Analysis of railway track geometry measurement methods usability
}

\begin{abstract}
Precise information of railway tracks geometry is necessary to design alignment project. Geodetic measurements are the most common method of determining this information and sags of arch direct measurement are the traditional and still popular measurement method. Development of geodetic measurements techniques made possible to use another methods such as tacheometry, GNSS, and new methods based on mobile measurement devices. Series of experiments were conducted to set the practical usability of selected modern measurement methods to design track alignment project. The experimental measurements were performed on the $3 \mathrm{~km}$ long two-track railway fragment. Following methods were used during the test measurements: sags of arch direct measurement, tacheometry with total station, GNSS, automated methods with the use of a trolley system. Above mentioned measurement methods were compared taking into account time and labour consumption, range of geometric data, measurement equipment cost, reliability and accuracy of surveying procedure. Because of different data types are delivered with various methods, sags of arch were used for comparison of accuracy. Comparison of geometrical data obtained with analysed methods allowed to formulate conclusions concerning practical usability those methods for track alignment project development.
\end{abstract}

Keywords: Track Geometry; Railway Track Alignment; Geodetic Measurements; Trolley Systems; GNSS

\section{Introduction}

A number of main railway lines are currently undergoing modernization to adapt these lines to $160 \mathrm{~km} / \mathrm{h}$. One of the elements of modernization is changing the geometry of the track axis necessary to ensure adequate traffic safety and driving comfort. This is especially important for routes intended for passenger trains. This is related to the necessity to maintain proper radius curves of circular arcs and appropriate lengths of transients. A separate category is railways of lower categories. In many cases, the condition of tracks on such lines indicates their significant deformations constituting a real threat to traffic safety and forcing speed limits (figure 1). Corrective actions for such sections often consist in regular changes in curvature of the track in a horizontal plane, while the project of regulation of the track axis is being developed based on the assumption of optimal geometry while minimizing track displacements. Strict adherence to the principle of minimizing displacements leads to the formation of a complex geometry of the axis of the regulated track. The implementation of such a project meets the basic goal, however, as the authors of the study [4] noted, a large number of geometric elements makes it difficult to maintain such a track. 


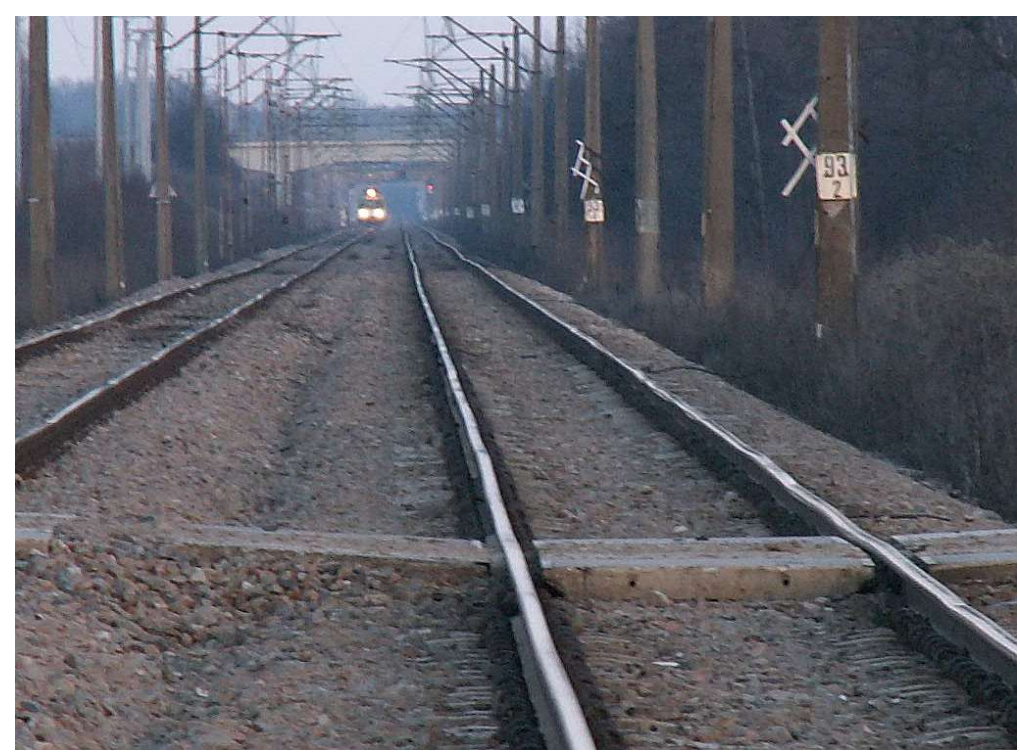

1. A fragment of a railway line with strongly deformed tracks

Regardless of the purpose and the assumptions adopted for the development of the railway line regulation project, detailed information on their actual geometrical condition is necessary. The source of accurate and reliable spatial information about the track are measurements made using geodetic methods.

\section{Geodetic measurements as a source of information about track axis geometry}

To determine the actual course of the track axis, various methods and measurement techniques are used, including:

- a method of direct or indirect measurement of arrows,

- polar method using tacheometers,

- methods using satellite observations,

- methods using various types of mechanical and electronic solutions, e.g. measuring cars, equipped with inclination sensors, extensometers and inertial devices, laser scanners and digital cameras.

These methods differ both in terms of the type of information provided, the accuracy, the costs of the necessary measuring elements, the labor-intensity of the measurement process and technical conditions that determine the possibility of making measurements with adequate accuracy. The method of geodetic measurements is determined by appropriate instructions, technical standards, and guidelines issued by entities managing railway infrastructure. The Ig6 guidelines [9] and the technical standard Ig-7 [10] defining the method of railway carcass construction as well as the technical standard GK-1 [8], replacing the previously applicable D-19 instruction [7], can be mentioned here. As the experimental measurements described in this study were performed at the request of the client in accordance with the instructions of D19 , the description of measurement activities will also cite this document.

The arrow measurement method has been used for a long time. It is simple and cheap to implement. The result of the measurement in this method is the distance of the test point on the track from the chord determined by the two reference points. A mechanical chord (string) or optical chord can be used - it is carried out using a supporting instrument. The length of the chord on which the arrow is measured depends on the curvature of the arc, with the same length of chords as on the following circular arc on the transition curve (with variable curvature value). The string is used for chords not exceeding $10 \mathrm{~m}$. For longer chords, the only theodolite is used. Regardless of the embodiment of the chord, the accuracy required for measuring the value of the arrow is approx. $\pm 1 \mathrm{~mm}$. The measurement of the arrows is done 
twice. In the case of theodolite measurement, there are two ways to measure the arrows: 1) direct way - where the chord is directly based on endpoints (Figure 2). 2) indirect way - where the measurement of arrows consisting of measurements similar to the so-called straight-line method. (Fig. 3).

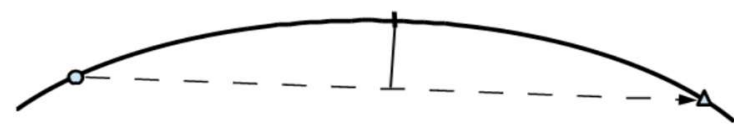

2. Direct measurement of arrows

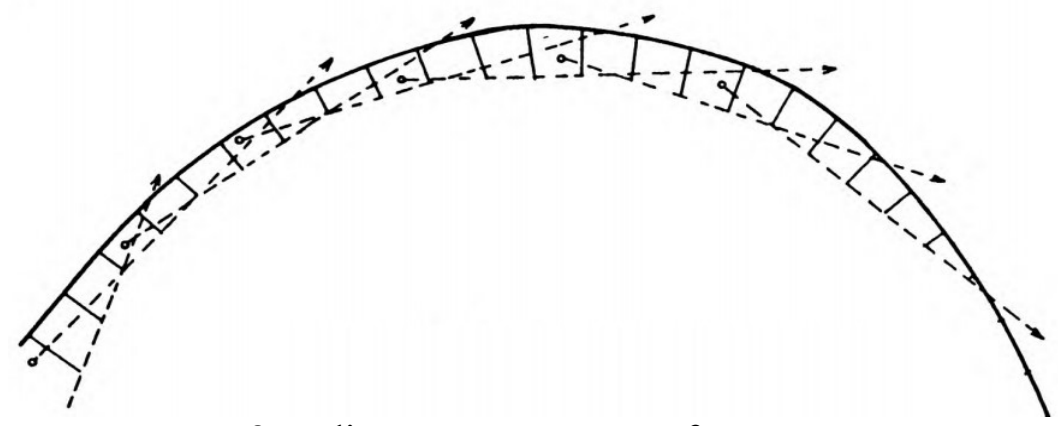

3. Indirect measurement of arrows

In the case of the indirect method, arrows for shorter chords can be obtained by appropriate conversion according to the formula (for equal distances between the measured points on the track):

$$
s_{i}=\mathrm{d}_{i}-\frac{d_{\mathrm{i}+1}+\mathrm{d}_{i-1}}{2}
$$

where: $d_{i}, d_{i-1}, d_{i+1}-$ measurements from the reference line on the current, previous and next point, respectively

The aim of the measurement is to obtain information about the geometry of the track axis. Meanwhile, one of the rails is measured. Therefore, especially in the case of small radii of curvature, what will be the difference between the arrow, the selected rail and the corresponding arrow of the track axis.

The values of the measured arrows also affect the way of identifying the inner rail edge. For measuring the geometry of the track axis, this edge (according to the instruction Id14 [12]) determines the cross-sectional point of the rail located $14 \mathrm{~mm}$ below the upper surface of the rail (Fig. 4a). This definition is included in the construction of measuring trolleys and track gauges used for railway measurements. Meanwhile, in the case of the direct method of measuring the arrows, the most prominent in the horizontal direction of the rail head is measured (Figure 4b). This results in the difference in the obtained measurement results $\Delta \mathrm{s}$. This value can have a significant value in the case of significant and uneven wear of rails (Fig. 4c). Due to the high labor consumption and susceptibility to measurement errors of a systematic nature, the method of direct measurement of the arrows is not recommended $[1,8]$. The method of direct measurement of the arrows is justified only in the case of short chords measured with a string. The accuracy of determining the course of the track using the 
arrow method allows using this method to develop track regulation projects as well as control measurements for railway lines even at high speeds (up to $200 \mathrm{~km} / \mathrm{h}$ ).

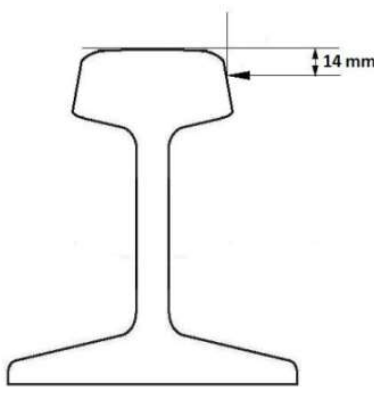

a)

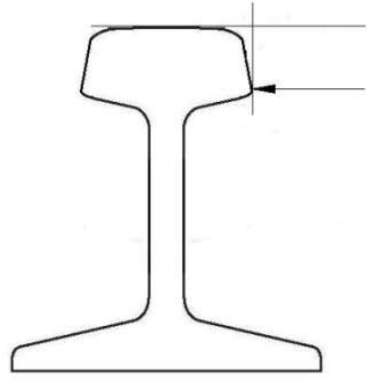

b)

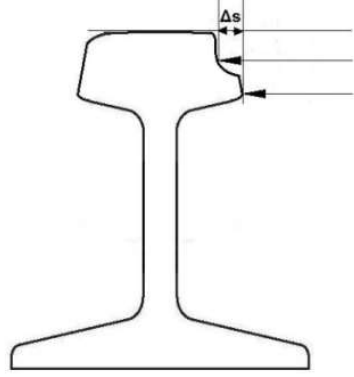

c)

4. The principle of determining the position of the measuring point on the head of the rail

Measurement of the course axis using the polar method (tacheometric) requires the use of a precise electronic station. According to the instruction D-19 [7], it should be a total station with an accuracy of angle measurement higher than $10 \mathrm{cc}$ and accuracy of distance measurement at least $\pm(10 \mathrm{~mm}+10 \mathrm{~mm} / \mathrm{km})$. The Ig-7 technical standard introduces the obligation to link the total station to at least three characters of the detailed railway carcass. The position determination error can in this case not exceed $\pm 15 \mathrm{~mm}$, and the target length to the measured point on the track (according to Ig-7) cannot exceed $200 \mathrm{~m}$. As a result of polar measurement, the positions of particular points determining the axis of the track are obtained. These points can be measured directly. In this case, it is necessary to use the right instrument to identify the axis of the track. On the straight line, the situation is straightforward because the track gauge is $1435 \mathrm{~mm}$. The track axis is usually defined as a line offset from one of the rails by half the clearance - or $717.5 \mathrm{~mm}$. An alternative way is to determine the point halfway between the rails. The device developed by the authors presented in Fig. 5 enables the location of the track axis halfway between the rails. Placing the reflector at the height of the upper surface of the railheads eliminates the influence of the device's slope on the measurement results, in the case of the transverse cant of the track on the arc sections. Another way to obtain the position of the axial point of the track is to calculate it based on the measured position of the points on the rails. This solution was used by the authors of the study [3].

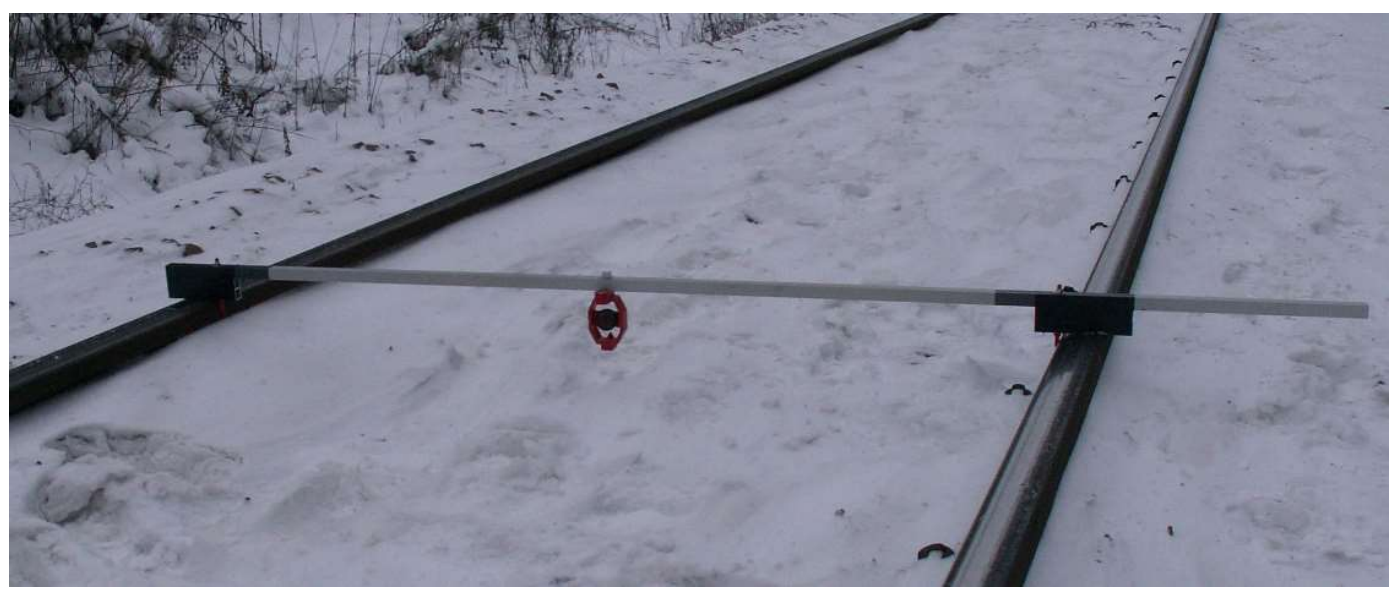

5. A device for identification and measurement of the track axis

There is a wide range of measuring devices qualified as so-called measuring carts. 
They operate on different principles and provide different types of sizes. Some of them are used to measure the local curvature of the track, others allow to obtain the positions of the axial points of the track. Both allow you to record the amount of transverse superelevation and the actual value of the track gauge. Description and analysis of the suitability of various types of measuring devices for measuring tracks include, inter alia, studies [5] and [6]. Among the methods using measuring carriages, two methods were analyzed and tested in practice:

- single-trolley method,

- twin-trolleys method.

Both methods allow obtaining the coordinates of the axial points of the measured track and two additional elements such as transversal cantilever and the track gauge. The singlebogie method uses one measuring trolley with a reverse reflector mounted on it as well as slope and rail gauge sensors and an electronic total station set up, similarly to the tacheometric method, in the area of the measured track (Figure 6). The tachometer station is established to the KOS points in the same way as in the tacheometric method. After making a full reference to the warp points, the tachometer switches to tracking mode of the reflector mounted on the trolley. In fixed places, the trolley is stopped, after which the measurement and registration of the reflector position are triggered. Regardless of the total station, the trolley measures inclination angles in the longitudinal and transverse direction as well as the track gauge. On the basis of these values, it is possible to determine the point of the axis of the track based on the position of the reflector placed - most often eccentrically - on the trolley. As a rule, the measurement of track axis points using the single-trolley method does not differ from the tachometric measurement. The most important differences result from the fact that the trolley method acquires additional track parameters, i.e. spacing and cant. These parameters are a valuable guide to conducting analyzes of the condition of the track and then to designing its regulation.

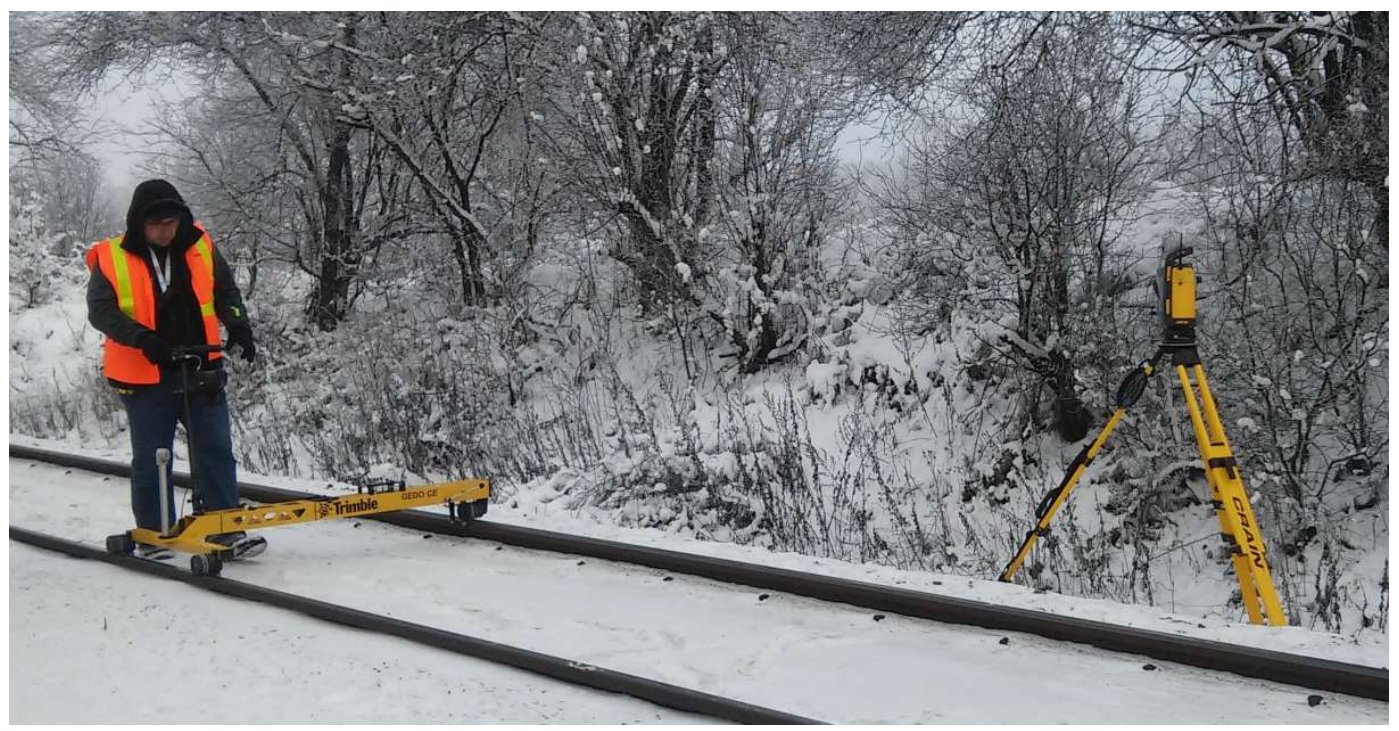

6. Track measurement using the single-trolley method

At the heart of the twin-trolley method is to strive to accelerate the measurement in order to be able to provide data to automated tamping machines in real time. This method uses two measuring carts, one of which is a total station carrier, and the other is used to collect data on track geometry - analogously to the single-trolley method. In the twin-trolley method, each position is covered by the so-called chord, i.e. the section between the station of the total station (on the trolley) and the last point of the track measured from the previous 
position (string). A simplified method of establishing a tachometer is used here. The track measurement scheme using the twin-trolley method is shown in Fig. 7. The trolley with the total station stops in front of the traction network post with the KOS sign (T1, T2 positions). Before commencing the correct measurement of the path with the reflector stroller, the total station is measured using the total KOS mark and the reflector on the second trolley ( $\mathrm{Wr} 0)$. The position of the stroller with the $\mathrm{Wr} 0$ reflector is known from the previous bench station. After this realization, measurement of the points of the track begins with the use of a stroller with a reflector (points Wr1 .. Wr5), the last - the nearest station - point Wr5 fulfills the function of the point of reference at the next station (trolley with tachometer).

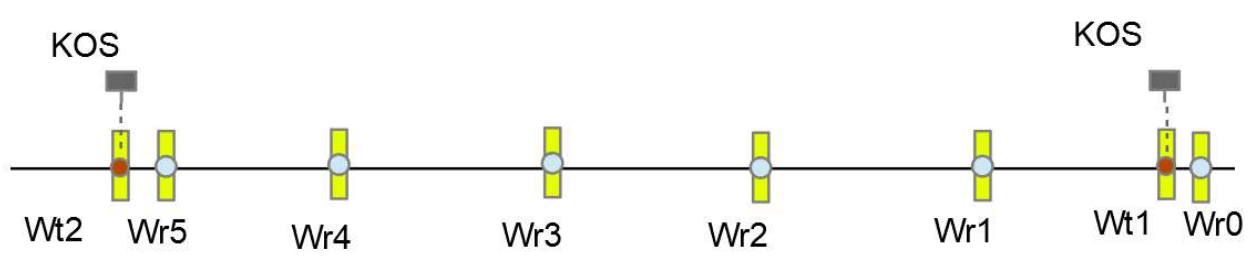

7. Track measurement scheme using the twin-trolley method

In the GNSS method, the satellite signal from available navigation systems and correction corrections of the ASP EUPOS system are used to determine the position of the point on the track. Depending on how you get corrective corrections, you can talk about the RTK system (a single reference station) or RTN (a correction based on many reference stations). Due to the limitations of accuracy, the usefulness of the results of measurements made using the satellite method for the regulation of the track axis has been the subject of numerous analyzes and experiments, among which you can list e.g. [4] and [6]. The accuracy of determining the coordinates depends on several factors:

- parameters of the receiver and its antenna,

- location of the reference station (or stations) with respect to the measurement location,

- instantaneous configuration of the satellites and the quality of indentation,

- location of terrain obstacles and interference with satellite signal reception.

The first two factors are fixed for a specific object. The next two change in time depending on the current prevailing terrain conditions. The accuracy of the obtained coordinates is usually evaluated by the software of the satellite receiver and displayed along with the obtained coordinates. The user may not always be able to reliably assess the magnitude of the influence of variable factors on the accuracy of determining coordinates. Fig. 8 shows a set for measuring the track axis using the GNSS method. Because the antenna is elevated to a certain height relative to the level of the railheads, it is necessary to measure longitudinal and transversal inclinations in order to eliminate the influence of the antenna eccentricity. 


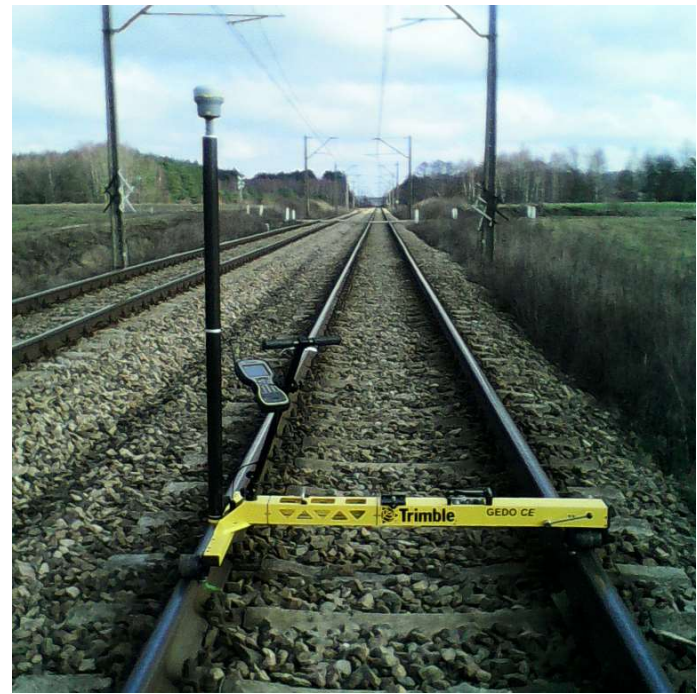

\section{Measurement experiment}

8. GEDO set for measuring GNSS tracks

In order to determine the practical usefulness of selected methods of measuring the geometry of the track axis to perform a track system control project, a series of test measurements were performed on a selected section of the operated railway line. This section was about $3 \mathrm{~km}$ long and was located on the double-track railway line No. 12 Skierniewice - Łuków between the villages of Osieck and Grabianka (Figure 9). From the geometric side, each track consisted of three straight sections and two curved lines. Each of the curved sections consisted of two basket arcs and two cloth boxes. Before the measurement of the track axis, a geodetic railway network was established. It consisted of a horizontal railway base carcass and a detailed railway carcass, so-called KOS. Both the basic and detailed network were measured in accordance with the recommendations of the technical standard Ig-7 [10]. The basic warp consisted of three pairs of points spaced about $1.5 \mathrm{~km}$ from each other (Figure 9). These points were measured using the satellite method. The detailed network was composed of 102 KOS characters, stabilized on traction network poles in accordance with the guidelines of Ig-6 [9]. A tripod method was used to measure the detailed matrix. The measurement was made in relation to the basic matrix.

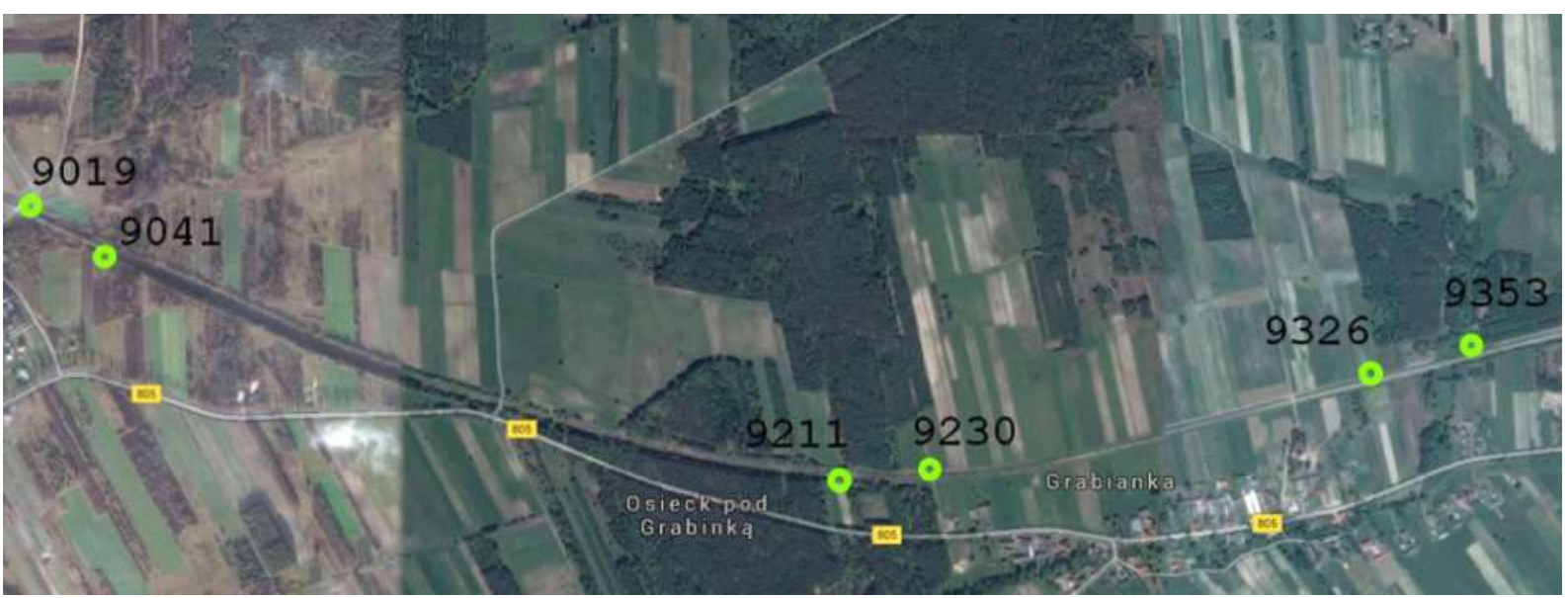

9. Arrangement of the basic warp points

The TDA 5005 total station was used to measure the detailed network, and the observations were made using the strict method. In this way, high accuracy of the position of all points in the railway network was obtained, which was a reference for all subsequent measurements carried out as part of the experiment. The coordinates of the warp points, both 
basic and detailed, were determined in two systems: PL 2000 (zone 7) and in the local system. For the local coordinate system, a Gauss-Krüger mapping with an axial meridian passing through the middle of the test section was assumed. The average level of terrain was assumed as the local altitude reference level. Thanks to such a local layout assumption, it was possible to neglect projection reductions to the measured distances without compromising the accuracy of determining the position of the characteristic points of the track. This solution was adopted to investigate the possibility of using different coordinate systems to develop the results of field measurements as well as to develop projects for regulation of track axes.

The geometry measurement was carried out independently of each of the five methods listed in the previous chapter. In the case of the arrow method as well as the tachymetric method for determining the track axis, the proprietary auxiliary device shown in Fig. 10 was used. In the "trolley" methods and in the GNSS method, the identification of the axial point of the track ( $14 \mathrm{~mm}$ below the running surface of the rails) was ensured by the construction of the trolley. In the arrow and tachymetric method, this function was performed by the device shown in photographs 5 and 10. Regardless of the method of measurement, the same points were placed at $20 \mathrm{~m}$ intervals on rectilinear lines and every $10 \mathrm{~m}$ on curved sections.

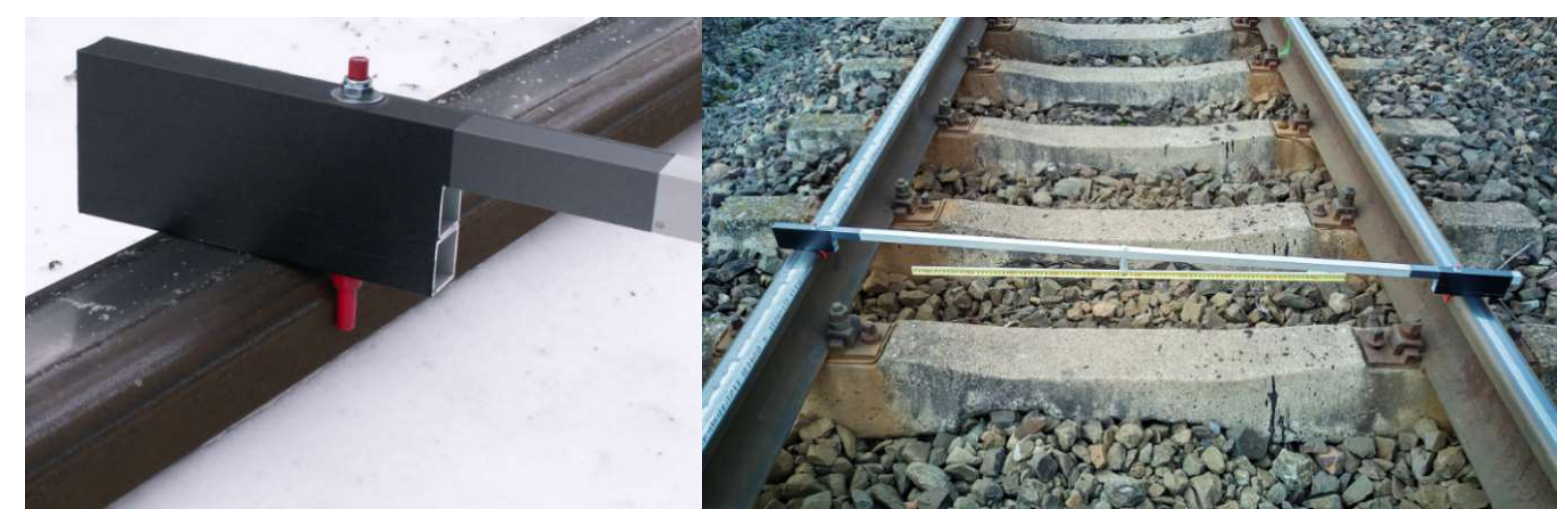

10. Auxiliary tool for determining the axis of the track

\section{Comparison of the results of experimental measurements}

The main purpose of the research work was to compare the usefulness of data obtained by means of various measurement methods, to develop a project to regulate the axis of the track.

Comparisons of this can be done in two ways:

- by comparing the resulting developed draft regulations,

- by comparing the results of spatial measurements of points representing the layout of the analyzed tracks.

The implementation of the first of these methods encounters the difficulty of an algorithmic nature. The authors [3] point out that the methods of designing the regulation vary depending on the type of source data. This applies in particular to the method of measuring the arrows, for which the control project is created in stages (first straight later, later arcs) [2]. Using the coordinates of the points of the specific track axis, using modern software, you can develop a regulation project in a one-step process. As a consequence, even draft regulations developed on the basis of identical data (e.g. on the basis of coordinates and arrows calculated on the basis of the same coordinates) will be different.

An attempt to compare the results of the measurement also encounters some difficulties. First of all, different methods provide different sizes of observed, which cannot be directly compared. Secondly, even in the case of methods supplying XY coordinates, there are differences resulting not from the accuracy of the measurement, but from the specific way of determining the measured point that is specific to the railway measurements. Track points to be measured are marked on the rails at set distances before starting the measurement. 
Instruction D-19 [7] imposed the use of a compressed steel strip for this purpose. However, even with the use of precise measuring equipment and careful marking of points on rails, the accuracy of their determination in the direction along the track axis will not be better than $1 \mathrm{~cm}$, while the identification of the track axis position in the transverse direction (according to the instruction Id-14) will be much more accurate. As a result, several measurements of the position of the same track point, even using the most accurate method will give different results. The geometric value enabling the comparison of the results of the measurement of the track axis by different methods can be the value of the track axis arrow. It is directly measured in the arrow method, and in the case of coordinate delivery methods, it can be calculated. At the same time, the value of the arrow is not very sensitive to minor differences in determining the place of measurement along the axis of the track. In connection with the above, the authors have compiled the values of arrows on the measured points of the axis of the track, and then analyzed the differences between the corresponding values of the arrows obtained from different measurement methods. Tables 1 and 2 contain a combination of arrow differences for all combinations of method pairs.

Tab. 1. Differences of corresponding arrows for track 1

\begin{tabular}{|c|c|c|c|c|c|}
\hline & arrows & tacheometry & 1 trolley & 2 trolleys & GNSS \\
\hline arrows & - & 1.5 & 1.1 & 1.0 & 6.4 \\
\hline tacheometry & 1.5 & - & 1.7 & 1.7 & 7.4 \\
\hline $\mathbf{1}$ trolley & 1.1 & 1.7 & - & 0.9 & 6.4 \\
\hline 2 trolleys & 1.0 & 1.7 & 0.9 & - & 6.5 \\
\hline GNSS & 6.4 & 7.4 & 6.4 & 6.5 & - \\
\hline
\end{tabular}

Tab. 2. Differences of corresponding arrows for track 2

\begin{tabular}{|c|c|c|c|c|c|}
\hline & arrows & tacheometry & $\mathbf{1}$ trolley & 2 trolleys & GNSS \\
\hline arrows & - & 1.6 & 1.3 & 1.2 & 8.1 \\
\hline tacheometry & 1.6 & - & 1.7 & 1.7 & 8.9 \\
\hline $\mathbf{1}$ trolley & 1.3 & 1.7 & - & 0.8 & 8.3 \\
\hline 2 trolleys & 1.2 & 1.7 & 0.8 & - & 8.2 \\
\hline GNSS & 8.1 & 8.9 & 8.3 & 8.2 & - \\
\hline
\end{tabular}

The values presented in the tables were obtained from the dependence:

$$
\mathrm{f}=\sqrt{\frac{\sum\left(s_{i}-s_{j}\right)^{2}}{n}}
$$

where:

$\mathrm{s}_{\mathrm{i}}, \mathrm{S}_{\mathrm{j}}$ - values of the corresponding arrows from the $\mathrm{i}$ and $\mathrm{j}$ methods,

$\mathrm{n}$ - number of common arrows designated by both methods

As can be seen, the best agreement of results was obtained for methods using measuring trolleys. The standard deviation for these cases was $\pm 0.8 \div 0.9 \mathrm{~mm}$. This is justified by the high quality of the measuring equipment used, and hence the precision of the measurement. Of equal importance was also the same (forced by the construction of the trolley) in both methods the identification of the measured point of the track axis. Slightly inferior conformity, because $\pm 1.0 \div 1.3 \mathrm{~mm}$, was obtained between the method of direct 
measurement of arrows and "trolley" methods.

For the tachymetric method, the compliance in the ratio of trolley methods as well as the method of direct measurement of arrows fluctuated at the level of $\pm 1.5 \div 1.7 \mathrm{~mm}$. Despite some differences in cross-compliance, these methods can be described as high-accuracy. The advantage of the tachymetric method, like the "trolley" methods, is the reference of results to the geodetic control network. The tachymetric method is much cheaper than trolley methods. The results obtained by the GNSS method differ significantly from this background. Compatibility in relation to other methods ranges from $6.4 \div 8.9 \mathrm{~mm}$, it should be noted that the measurement with this method was made on a section of the track with optimal conditions for satellite measurement. In addition, it should be remembered that the satellite measurement technology requires visibility of the respective constellation of satellites. This condition is not always possible (wooded area, built-up, viaducts, tunnels, etc.). In these situations there will be a significant decrease in accuracy or measurement will be impossible. Based on the tests and the accuracy requirements specified in Annex 13 to the Instruction Id-1 [11], it is possible to determine the range of usefulness of the described methods for the design of the track axis adjustment and for measuring the control track axis (Table 3 ).

Tab. 3. The maximum design speed of the route for individual methods of measuring the axis of the track

\begin{tabular}{|c|c|}
\hline measurement method & $\begin{array}{c}\text { method of measuring the maximum design } \\
\text { speed of the route }[\mathbf{k m} / \mathbf{h}]\end{array}$ \\
\hline measurement of arrows & 200 \\
\hline tacheometry & 200 \\
\hline 1 trolley & 200 \\
\hline 2 trolleys & 200 \\
\hline GNSS & 100 \\
\hline
\end{tabular}

The satellite method does not allow obtaining data on local deformations of the axis of the track with accuracy comparable to other methods, but it has an important advantage. It does not generate an increase in errors with the increase of the length of the measured track section, thus enabling the development of a control project in a uniform coordinate system. The authors of studies [4] and [1] drew the attention to the advantages of using GNSS measurements for tasks related to tracking regulation. This method is very simple to implement and is great for measuring automation. A further increase in the possibility of satellite measurements will be possible after the use of inertial sensors allowing the recording of measurement data also in the event of a satellite signal loss.

\section{Summary}

As a result of the measurements carried out on the test section, a number of conclusions can be drawn regarding the suitability of the tested methods of measuring the track axis to conduct the process of regulation of the track system status. The selection of the optimal method of measuring the geometry of the track system depends on the technical and economic conditions of the contractor and the conditions prevailing in the field. By focusing on the speed of the measurement and the range of acquired data on track geometry, automatic systems such as measuring systems using measuring cars will be the optimal choice. It is worth noting that in automated measuring systems, apart from the position of the track center points, the track gauge, as well as the cant and longitudinal inclination of the track at the measurement points are also recorded. Traditional arrow measurement allows you to get data about the local geometry of the track in a relatively simple way and with inexpensive 
equipment. The advantage of this method is high relative accuracy, while its shortcomings are the inability to automate the measurement and the resulting higher labor intensity than other methods. Besides, having only information about the local curvature of the track, we can not use modern software allowing for a comprehensive development of the draft regulation.

The advantage of the GNSS method is its simplicity and speed of measurement. Not without significance is the insensitivity of this method to local changes in the accuracy of the geodetic control network. Thanks to the ASG-EUPOS system support, only one satellite receiver is sufficient to perform the measurement. The use of a satellite car as a carrier for the measurement significantly improves the measurement. Obtained accuracy of results gives way to the accuracy of other measurement methods in the field of local changes. A compromise solution between very technically advanced and effective methods of so-called "trolley and the simple, cheap, arrow method, is the tachymetric method. This method is characterized by high accuracy and is free from increasing errors of systematic arrow methods. In order to increase the accuracy of the measurement, it is advisable to use the track gauges. The most suitable solution for comprehensive spatial measurement of tracks will be the use of solutions with measuring trolleys. The measurement is fast, reliable and meets all the accuracy requirements of railway measurement standards. An important advantage is also the far-reaching automation of the measurement process.

\section{Source materials}

[1] Dobrowolski B., Koncepcja numerycznego modelu geometrii torów w procesie napraw nawierzchni. TTS Technika Transportu Szynowego, 2002 (9), s. 58-67

[2] Dobrowolski B., Geodezja kolejowa. SGP Oddział w Katowicach, Katowice 2014

[3] Jamka M., Lisowski S., Strach M., Zastosowanie nowoczesnych technik pomiaru i oprogramowania do regulacji osi torów. TTS Technika Transportu Szynowego 2009 (15), s. 55-61

[4] Koc W., Chrostowski P., Grzejka P., Specht C., Lewiński L., Ocena efektów regulacji osi toru na wybranej linii kolejowej. TTS Technika Transportu Szynowego, 2013 (20), s. $81-84$

[5] Strach M., Pomiary dróg kolejowych i obiektów z nimi związanych oraz opracowanie wyników na potrzeby modernizacji kolei konwencjonalnych. Archiwum Fotogrametrii, Kartografii i Teledetekcji, 2009, Vol. 19, s. 411-421

[6] Strach M., Piekarz M., Nowoczesne urządzenia w pomiarach dróg kolejowych. Problemy kolejnictwa, 2009, Zeszyt 148, s. 48-60.

[7] Zarząd PKP, Instrukcja o organizacji i wykonywaniu pomiarów w geodezji kolejowej D-19. Załącznik do Zarządzenia Nr 144 z dnia 23 października 2000 r.

[8] Zarząd PKP S.A. Standard techniczny „o organizacji i wykonywaniu pomiarów w geodezji kolejowej GK-1, Załącznik do uchwały Nr 8 z dnia 12 stycznia 2016 r.

[9] Zarząd PKP Polskie Linie Kolejowe S.A. Wytyczne dla osadzania znaków regulacji osi toru na konstrukcjach wsporczych (słupach) sieci trakcyjnej Ig-6. Załącznik do zarządzenia $\mathrm{Nr}$ 24/2011 z dnia 18 lipca 2011 r.

[10]Zarząd PKP Polskie Linie Kolejowe S.A. Standard techniczny określający zasady i dokładności pomiarów geodezyjnych dla zakładania wielofunkcyjnych znaków regulacji osi toru Ig-7. Zał. do zarządzenia Nr 27/2012 z dnia 19 listopada 2012 r.

[11]Zarząd PKP Polskie Linie Kolejowe S.A. Warunki techniczne utrzymania nawierzchni na liniach kolejowych Id-1, Za łącznik do zarządzenia Nr 14/2005 z dnia 18 maja 2005 r. z późniejszymi zmianami.

[12]Zarząd PKP Polskie Linie Kolejowe S.A. Instrukcja o dokonywaniu pomiarów, badań i oceny stanu torów Id-14 (D-75). Za łącznik do zarządzenia Nr 26/2005 z dnia 12 lipca $2005 \mathrm{r}$. 